$14^{\text {th }}$ Conf. Agric. Dev. Res., Fac. Agric., Ain Shams Univ.,

March, 2019, Cairo, Egypt

Special Issue, 27(1), 775 - 785, 2019

Website: http://strategy-plan.asu.edu.eg/AUJASCI/

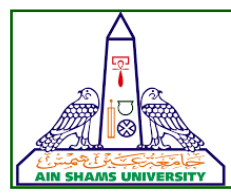

775

\title{
IMPROVING THE FRUIT YIELD AND QUALITY OF CUCUMBER BY GRAFT- ING ONTO DIFFERENT ROOTSTOCKS UNDER SALINE CONDITIONS
}

Mohammed, S.M. ${ }^{1}$; Ragab M.E. ${ }^{2}$; Metwaly H.G. ${ }^{2}$ and Kabeel S.M. ${ }^{1}$

1. Protected Cultivation Dept., Hort. Res. Inst., Agric. Res. Center, Giza, Egypt

2. Horticultural Dept., Fac. of Agric., Ain Shams Univ., P.O. Box 68, Hadyek Shoubra, 11241 Cairo, Egypt

*Corresponding author: Mohamed_emam@agr.asu.edu.eg

Received16 September, 2018, $\quad$ Accepted 25 September, 2018

\section{ABSTRACT}

Two experiments were carried out under low polyethylene tunnels which furnished with drip irrigation during the two successive winter seasons of 2014-2015 and 2015-2016 at Elbrollous area which represents the circumstance and conditions of coastal zone of north Nile Delta kafr Elsheikh Governorate. The objective of the investigation was to find out the effect of grafting by different cucurbita rootstocks on cucumber hybrid "ESHRAK" (Cucumis sativus, L.) on vegetative growth, flowering, yield and fruit characteristics, beside nutrient contents of cucumber plants. Results showed that grafted cucumber plants on Super Shintoza led to significant increase in vegetative growth,i.e., stem length, number of leaves, number of branches and leaf area,fruit fresh weight (g), number of fruits, total yield were greater with grafted cucumber plants on Super Shintoza followed by grafted cucumber plants on cv. Ferro. However grafting had no significant effect on potassium \% of fruit on both seasons. The highest total yield was obtained by grafting cucumber plants on Super Shintoza rootstock followed by grafting on cv. Ferro rootstock by $130 \%$ and $73 \%$, respectively in the first season and $160 \%$ and 147 $\%$, in the second season respectively as compared with ungrafted cucumber plants. Accordingly, this study ensured that the use of rootstocks were more beneficial than ungrafted cucumber in both tested seasons.

Keywords: Cucumis sativus, salt stress, grafting

\section{INTRODUCTEION}

Cucumber (Cucumis sativus, I.) is one of the important vegetable crops belongs to family $\mathrm{Cu}$ curbitaceous. The cucumber cultivated area in Egypt reached about 69000 feddan in 2015. This area produces about 630 thousand tons, with an average of about 9 tons / feddan according to (Ministry of Agriculture, 2015).

Salinity is known as the most important a biotic stress changes the anatomy and morphology of plants. The cucumber is a sensitive vegetable crop to salinity of irrigation water up to 2 mellimos. Due to limited availability of arable land and high market demand for off-season vegetables, cucurbits (including cucumber) are continuously cultivated under unfavorable conditions in some countries such as salinity, drought, low temperature, wet and low-light winter greenhouses. Successive cropping can increase salinity, the incidence of cucurbit pests, and soil borne diseases like fusarium wilt caused by Fusarium spp. These conditions cause various physiological and pathological disorders leading to severe crop loss. Chemical pest control is expensive, not always effective, and can contaminate the environment. Grafting can overcome many of these problems (Singh and Rao 2014). Chlorophyll, carotenoid contents, stomata length and width of upper and lower surface of leaf were generally reduced under salinity stress (Yars et al 2017).

Colla et al (2010b) and Fallik \& Ilic (2014) mentioned that grafting vegetables can protect against soil-borne diseases and nematodes, against a biotic stress such as high/low temperatures, salinity, soil alkalinity, drought or excessive 
soil-water content. Farhadi and Rezaie (2015) reported that use of grafted seedlings increased in greenhouses due to enhancement of fruit quality and increase yield where production faces with unsuitable suboptimal conditions from late fall to early spring such as low temperature, low light intensity, high humidity and salinity. Rouphael et al (2017) indicated that the use of grafted vegetable plants can minimize problems associated with successive cropping and a biotic stress, and the enhanced vigour and root growth can provide yield benefits independently from mechanisms to tolerate abiotic stress conditions. Therefore, the application of grafting in crops of the cucurbitaceous and Solanaceae is currently acknowledged worldwide; however, two main challenges remain when grafted plants are used as a tool to improve a biotic stress tolerance.

Grafting increases the ability of plants to absorb water and nutrients from the soil. Colla et al (2012) found that grafted cucumber plants exposed to $\mathrm{Na}_{2} \mathrm{SO}_{4}$ were capable of maintaining a better nutritional status (higher $\mathrm{K}, \mathrm{Ca}$ and $\mathrm{Mg}$ and lower $\mathrm{Na}$ ) in the shoot tissues and higher membrane selectivity in comparison with ungrafted ones. Lei et al (2014 a) showed that the $\mathrm{NaCl}$ treatment decreased content of $\mathrm{Ca}_{2}+$ and $\mathrm{K}+$ but increased the $\mathrm{Na}+$ content in roots and shoots. Yang et al (2015) found that the bottle gourd rootstock-grafted seedlings could maintain much higher $\%$ of $\mathrm{K}^{+}$and a higher ratio of $\mathrm{K}^{+} / \mathrm{Na}^{+}$in all the organs as compared with self-grafted seedlings. This could do the favor to maintain the ion homeostasis for a plant exposed to the salt stress.

Grafting increases, the period of growth and harvest, which stimulates the growth of plants. Davis et al (2008) and King et al (2010) mentioned that use of rootstocks can enhance plant vigor through vigorous attainment of soil nutrients, avoidance of soil pathogens and tolerance of low soil temperatures, salinity, and wet-soil conditions. The type of rootstock affects cucurbit plant growth, yield, and fruit quality. Wang LiPing et al (2012), Zhao Yuan and Wu FengZhi (2014) and Farhadi and Rezaie (2015) reported that the rootstockgrafted cucumber showed improved plant growth significantly compared to non grafted ones.

Grafting increases crop productivity. Whereas, Huang Yuan et al (2009 a) and Marsic \& Jakse (2010) showed that grafted cucumber plants had higher fruit number, marketable and total fruit yield than those of self-grafted cucumber plants under saline condition. Cucumber plants decrease their productivity and fruit quality by increasing the salin- ity of irrigation water or soil in some areas irrigated with saline water such as the area of El-borollous.

Therefore, this research aims to improve the productivity and quality of cucumber fruit under saline conditions by cultivating the grafted cucumber seedlings on different tolerant rootstocks to saline conditions.

\section{MATERIAL AND METHODS}

Experiments were carried out under low polyethylene tunnels at borollous site, Kafr EISheikhGovernorate, North Nile Delta during the two successive seasons of 2014-2015 and 2015-2016 to investigate the effect of grafting on plant growth, yield and its components as well as fruit quality of sensitive cucumber plants to salinity. The effect of grafting on cucumber plants was studied under salinity condition Plant growth, flowering, fruit yield and quality characteristics and nutrient contents of the popular tunnels cucumber cultivar (cucumis sativus) (F1 hybrid Eshrak as scion) grafted on different cucurbita rootstocks were tested. The study included five genotypes of cucurbita rootstocksShintoza viz, (cucurbita maxima ${ }^{*}$ cucurbita moschata), Ferro (cucurbita maxima*cucurbita moschata), pumpkin (cucurbita moschata), winter squash (Cucurbita pepo) and bottle gourd (Lagenaria siceraria) to examine their relative tolerance to salinity by determining some physiological and chemical parameters associated with their sensitivity or tolerance to salinity.

The experimental design was complete randomized block design with three replicates. The experimental plot consisted of six treatments. Each treatment was layed in one ridge of $60 \mathrm{~m}$ long and $1 \mathrm{~m}$ wide. Seedlings were planted on the two sides of each ridge at $50 \mathrm{~cm}$ apart, and each plot contained 120 plants.

\section{Plant materials and grafting technique}

Seeds of Shintoza supreme pumpkin and Ferro were obtained from Rijk-zwaan company and the seeds ofcucumber cultivar(F1 hybrid 'Eshrak), pumpkin, winter squash and Bottle gourd were kindly taken from Horticulture Research Institute. Seeds were sown on 15 and 20 on November in first and second seasons respectively in trays (84 cells) filled with mixture of peat: vermiculite $(1: 1, v$ : v). The seeds of bottle gourd rootstock were sown 6-10 days later than the seeds of the scion to ensure similar stem diameters at the grafting time 

under saline conditions

due to the differences in growth vigor. Hole insertion grafting technique was used.

\section{The recorded data}

\section{Vegetative growth measurements}

Five plants were chosen random from each experimental plot at 70 days after transplanting for recording the following data: - Plant length $(\mathrm{cm})$, number of leaves and branches per plant, average leaf area (cm2), fresh and dry weight of leaves and stem/plant (g)were determined.

Fruit yield and its components as well as its quality

The different fruit yield characteristics were measured at harvesting time (marketable stage) in all picked fruits for calculating number of fruits perplant, average fruit weight ( $\mathrm{gm})$, plant total yield. (Kg /plant) and plant total yield. (ton /fed.): All fruits harvested from each treatment along the harvesting period were weighed to calculate the total yield per feddan. Representative samples of ten fruits were taken from each treatment at harvesting time; the average fruit firmness was measured. The total soluble solids (T.S.S) in fruits were determined using a hand refractmeter according to A.O.A.C. (1996).

Table 1. Water analyses of the experimental farm.

\section{Chemical constituents}

Potassium and sodium \% in fruits were determined by using flame photometer according to Jackson (1967). Chloride concentration was determined according to Ramsay et al (1955).

\section{Leaf Relative Water Content (LRWC)}

It was determined according to Yamasaki and Dillen burg (1999), the LRWC was calculated using the following formula: LRWC \% = (fresh weightdry weight) / fresh weight at full turgor - dry weight) $\times 100$

\section{Membrane permeability}

It was measured according to (Shi et al 2006) the electrical conductivity was calculated as (EC1) / (EC2) and expressed as percentage.

\section{Determination of proline}

Proline concentration was determined using the method described by Sadasivam and Manickam (1992).

\section{Soil and water analysis}

Soil and water samples were taken from the farm before and after planting for mechanical and chemical analyses which represented in Tables (1, 2, 3 and 4). Soil samples were analyzed at the Soil and Water Research Institute, ARC, Giza.

\begin{tabular}{|c|c|c|c|c|c|c|c|c|c|}
\hline \multirow{2}{*}{$\begin{array}{c}\mathrm{EC} \\
\mathrm{DS} / \mathrm{m}\end{array}$} & \multirow{2}{*}{$\mathrm{pH}$} & \multicolumn{4}{|c|}{ Cations meg/ $\mathrm{I}^{-}$} & \multicolumn{4}{c|}{ Anions meg/ I } \\
\cline { 3 - 10 } & & $\mathrm{Ca}^{2+}$ & $\mathrm{Mg}^{2+}$ & $\mathrm{Na}^{+}$ & $\mathrm{K}^{+}$ & $\mathrm{Cl}^{-}$ & $\mathrm{HCO}_{3}^{-}$ & $\mathrm{SO}_{4}{ }^{2-}$ & $\mathrm{CO}_{3}{ }^{2-}$ \\
\hline 3.65 & 7.8 & 6.8 & 8.34 & 25.1 & 0.72 & 21.43 & 5.3 & 7.2 & 6.5 \\
\hline
\end{tabular}

Table 2. Mechanical analysis of the soil in the experimental farm.

\begin{tabular}{|c|c|c|c|c|}
\hline Depth & Clay \% & Silt \% & Sand \% & Texture \\
\hline $10 \mathrm{~cm}$ & 7 & 5 & 88 & Sandy soil \\
\hline
\end{tabular}

Table 3. Chemical properties of soil samples before planting.

\begin{tabular}{|c|c|c|c|c|c|c|c|c|c|c|}
\hline \multirow{2}{*}{ Depth } & \multirow{2}{*}{$\begin{array}{c}\mathrm{EC} \\
\mathrm{DS} / \mathrm{m}\end{array}$} & \multirow{2}{*}{ pH } & \multicolumn{4}{|c|}{ Cations meg/l } & \multicolumn{4}{|c|}{ Anions meg/ I' } \\
\hline & & & Ca2+ & Mg2+ & $\mathrm{Na}+$ & $\mathrm{K}+$ & $\mathrm{Cl}-$ & $\mathrm{HCO}_{3}^{-}$ & $\mathrm{SO}_{4}{ }^{2-}$ & $\mathrm{CO}_{3}{ }^{2-}$ \\
\hline $10 \mathrm{~cm}$ & 1.5 & 8.2 & 2.5 & 1.3 & 2.2 & 1.5 & 2.1 & 1.86 & 1.4 & 4.5 \\
\hline
\end{tabular}


Table 4. Chemical properties of soil samples after planting.

\begin{tabular}{|c|c|c|c|c|c|c|c|c|c|c|}
\hline \multirow{2}{*}{ Depth } & \multirow{2}{*}{$\begin{array}{c}\text { EC } \\
\text { DS/m }\end{array}$} & pH & \multicolumn{3}{|c|}{ Cations meg/ I } & \multicolumn{3}{c|}{ Anions meg/ I } \\
\cline { 3 - 11 } & & $\mathbf{C a}^{2+}$ & $\mathbf{M g}^{2+}$ & $\mathbf{N a}^{+}$ & $\mathrm{K}^{+}$ & $\mathbf{C l}^{-}$ & $\mathbf{H C O}_{3}^{-}$ & $\mathbf{S O}_{4}{ }^{2-}$ & $\mathbf{C O}_{3}{ }^{2-}$ \\
\hline $10 \mathrm{~cm}$ & 1.01 & 7.8 & 1.38 & 0.8 & 2.11 & 0.3 & 1.5 & 1.6 & 0.67 & 4.3 \\
\hline
\end{tabular}

\section{Statistical analysis}

Growth parameters and chemical analysis were performed with analysis of variance using. Analysis of variance was performed for the transformed data using the method described by Gomez and Gomez (1983).

\section{RESULTS AND DISCUSSION}

\section{1- The effect of different rootstocks on vegeta- tive growth characteristics}

Data presented in Table (5) showed the effect of grafting combinations on vegetative growth characters, i.e., stem length, number of branches, number of leaves, leaf area.

Concerning stem length,the highest value was obtained by graft combinations of cv. Eshrak/ Shintoza in both seasons, while the lowest value was recorded in cv. Eshrak (un-grafted plant) in the first season and it was recorded on cv. Eshrak/ Pumpkin in the second season. Results were obtained by El- Wanis et al (2012), Zhao Yuan and Wu FengZhi (2014) and Farhadi \& Rezaie (2015). They found that the plant height was greater for grafted plants compared to non grafted ones.

Concerning number of branches, The highest value was obtained by Eshrak/Shintoza and Eshrak/Ferro in the first season and it was with Eshrak/Shintoza, Eshrak/ Ferro, Eshrak/ Bottle Gourd, and Eshrak/Squash without significant differences among them in the second season while the lowest value was with Eshrak (ungrafted) plants in both season and it was with Eshrak Squash in the first season. The Results indicated that grafted plants had the highest number of branches/plant. These results are in harmony with the previous work of Mohamed et al (2014) in grafted watermelon, The different genetic background of the different rootstocks was associated with their different rooting and tolerance characteristics to biotic and abiotic stress could explain the observed different impacts of rootstock on vegetative growth.

Regarding number of leaves, the effect of graft combinations on number of leaves was significant in both seasons for all combinations except Eshrak/ Shintoza, Eshrak/ Ferro and Eshrak/ Bottle Gourd, in the second season. The highest values were obtained by Eshrak/Shintoza in the first season and it was with Eshrak/Shintoza, Eshrak/ Ferro and Eshrak/ Bottle Gourd without significant differences in the second season while the lowest value was with Eshrak/ Squash in the first season and it was with Eshrak (ungrafted) plants in second season. these results agree with those of El- Wanis et al (2012), who showed that leaf number was greater for grafted plants compared to non grafted ones.

Concerning leaf area, the highest value was obtained by Eshrak/Shintoza and Eshrak/ Ferro in the first season and it was with Eshrak/Shintoza and Eshrak/ Squash without significant differences in the second season while the lowest value was with Eshrak ungrafted plants in both seasons without significant differences with Squash in the first season. Such results were confirmed by those of El- Wanis et al (2012) and Petropoulos et al (2012) they showed that leaf area index was greater for grafted plants compared to non grafted ones. 

under saline conditions

Table 5. Effect of grafting on Eshrak cucumber plantstem length, number of branches, number of leaves and leaf area per plant of cucumber during (2014/2015 and 2015/2016) seasons.

\begin{tabular}{|c|c|c|c|c|c|c|c|c|}
\hline \multirow{2}{*}{$\begin{array}{c}\text { Treatments } \\
1^{\text {st }} \\
\text { season } \\
\end{array}$} & \multicolumn{2}{|c|}{ Stem Length (cm) } & \multicolumn{2}{|c|}{ Number of Branches } & \multicolumn{2}{|c|}{ Number of leaves } & \multicolumn{2}{|c|}{ Leaf area $\left(\mathrm{cm}^{2}\right)$} \\
\hline & $\begin{array}{c}2^{\text {nd }} \\
\text { season }\end{array}$ & $\begin{array}{c}1^{\text {st }} \\
\text { season }\end{array}$ & $\begin{array}{c}2^{\text {nd }} \\
\text { season }\end{array}$ & $\begin{array}{c}2^{\text {nd }} \\
\text { season }\end{array}$ & $\begin{array}{c}1^{\text {st }} \\
\text { season }\end{array}$ & $\begin{array}{c}1^{\text {st }} \\
\text { season }\end{array}$ & $\begin{array}{c}2^{\text {nd }} \\
\text { season }\end{array}$ & $\begin{array}{c}2^{\text {nd }} \\
\text { season }\end{array}$ \\
\hline C & $90.9 \mathrm{E}$ & $97.0 \mathrm{D}$ & $2.67 \mathrm{C}$ & $3.00 \mathrm{C}$ & $72.6 \mathrm{D}$ & $66.0 \mathrm{D}$ & $116 \mathrm{D}$ & $112.2 \mathrm{D}$ \\
\hline $\mathrm{C} / \mathrm{Sh}$ & $185.8 \mathrm{~A}$ & $173.9 \mathrm{~A}$ & $6.67 \mathrm{~A}$ & $5.33 \mathrm{AB}$ & $132.0 \mathrm{~A}$ & $109.7 \mathrm{~A}$ & $176.7 \mathrm{~A}$ & $180.9 \mathrm{~A}$ \\
\hline $\mathbf{C} / \mathbf{F}$ & $173.4 \mathrm{~B}$ & 156.6 B & $6.00 \mathrm{~A}$ & $5.67 \mathrm{~A}$ & 107.3 B & $114.7 \mathrm{~A}$ & $179.7 \mathrm{~A}$ & $161.0 \mathrm{~B}$ \\
\hline $\mathrm{C} / \mathrm{P}$ & $103.5 \mathrm{D}$ & $86.0 \mathrm{E}$ & $3.33 \mathrm{BC}$ & $4.00 \mathrm{BC}$ & $89.33 \mathrm{C}$ & $83.00 \mathrm{~B}$ & $146.0 \mathrm{~B}$ & $142.7 \mathrm{C}$ \\
\hline C /B & $121.1 \mathrm{C}$ & $144.8 \mathrm{C}$ & $4.00 \mathrm{~B}$ & $4.67 \mathrm{AB}$ & $105.3 \mathrm{~B}$ & $110.0 \mathrm{~A}$ & $138.0 \mathrm{C}$ & $153.8 \mathrm{~B}$ \\
\hline $\mathrm{C} / \mathrm{Sq}$ & 99.4 DE & $143.3 \mathrm{C}$ & $2.67 \mathrm{C}$ & $5.33 \mathrm{AB}$ & $66.67 \mathrm{E}$ & $76.67 \mathrm{C}$ & 110.7 D & $172.4 \mathrm{~A}$ \\
\hline
\end{tabular}

Means followed by the same letter are statistically not significant according Duncan's multiple rang test $(P=0.05)$

C: Cucumber Sh: Shintoza F: Ferro P: Pumpkin B: Bottle Gourd Sq: Squash

\section{2- Effect of different rootstocks on yield and its components}

Data presented in Table (6) showed that all the five used rootstocks gradually and increased yield and its components significantly i.e., fruit weight, fruit number, total yield per plant and total yield per feddan compared with control (ungrafted cucumber)

Data in Table (6) showed that the differences in fruit weight were significant in both seasons. The highest value was recordedonEshrak/Shintoza in both seasons while the lowest value was in Eshrak/squash in the first season and Eshrak (ungrafted) plants in both seasons. These results are in agreement with that of Zhou JunGuo et al (2010) and El- Shraiy et al (2011).

Regarding number of fruits, results indicated that the highest value recorded on Eshrak/ Shintoza and Eshrak/ Ferro without significant differences in the first season and it was also with Eshrak/ Shintoza in second season while the lowest value was with Eshrak (ungrafted) plants, Eshrak/ pumpkin and Eshrak/ Bottle Gourd in both seasons. These results are in agreement with that obtained by Huang Yuan et al (2009) and El- Shraiy et al (2011).

Concerning total yield per plant and per feddan. Data indicated that using grafting increased total yield significantly in both seasons except Eshrak/ Shintoza and Eshrak/ Ferro in the second season. The highest value was obtained by Eshrak/ Shintoza in the first season and it was with Eshrak/ Shintoza and Eshrak/ Ferro without significant differences between them in the second season while the lowest value was with Eshrak (ungrafted) plants in both seasons.

In conclusion, data in Table (6) showed that number of fruits per plant was the main characteristic which affected yield for all different rootstocks. Therefore, the improving effect of different rootstocks in this respect is mainly attributed to the number of flowers per plant and fruit set percentage which, in turn, resulted in high yield. Obtained results are in agreement with that of Farhadi and Rezaie (2015) and Wang Qing et al (2017). They mentioned that the higher crop performance of grafted (Ekron/Affyne) cucumber recorded with $\mathrm{NaCl}$ than with $\mathrm{CaCl}_{2}$ was attributed to the limited capability of the rootstocks to restrict $\mathrm{Cl}^{-}$shoot uptake, thus $\mathrm{Cl}^{-}$, which continues passing to the leaves, becomes the more significant toxic component of the saline solution.

\section{3- Effect of different rootstocks on Chemical composition}

\section{A- Leaf relative water content (LRWC \%)}

Results in Table (7) showed that the highest leaf relative water percentage was recorded in grafted cucumber plants on Ferro and squash cv. without significant differences in the first season while in the second season, the highest percentage was found with cucumber grafted plants on Ferro and Shintoza without significant differences as compared to all graft combinations. The lowest percentage of leaf relative water content was obtained with ungrafted plants (control) in both seasons. These results are in agreement with that recorded by Colla et al (2010 a). 
Table 6. Effect of grafting on Eshrak cucumber plant fruit fresh weight (g), number of fruits and total yield (Kg/plant) of cucumber during (2014/2015 and 2015/2016) seasons.

\begin{tabular}{|c|c|c|c|c|c|c|c|c|}
\hline Treatments & \multicolumn{2}{|c|}{$\begin{array}{c}\text { Fruit fresh } \\
\text { weight } \mathbf{( g )}\end{array}$} & \multicolumn{2}{c|}{$\begin{array}{c}\text { Number } \\
\text { of fruits }\end{array}$} & \multicolumn{2}{c|}{$\begin{array}{c}\text { Total yield } \\
\text { (Kg/plant) }\end{array}$} & \multicolumn{2}{c|}{$\begin{array}{c}\text { Total yield } \\
\text { (ton/Fed.) }\end{array}$} \\
\hline $\begin{array}{c}\text { Scion / } \\
\text { stocks }\end{array}$ & $\begin{array}{c}\mathbf{1}^{\text {st }} \\
\text { season }^{\text {nd }}\end{array}$ & $\begin{array}{c}\mathbf{2}^{\text {nd }} \\
\text { season }\end{array}$ & $\begin{array}{c}\mathbf{1}^{\text {st }} \\
\text { season }\end{array}$ & $\begin{array}{c}\mathbf{2}^{\text {nd }} \\
\text { season }\end{array}$ & $\begin{array}{c}\mathbf{1}^{\text {st }} \\
\text { season }\end{array}$ & $\begin{array}{c}\mathbf{2}^{\text {nd }} \\
\text { season }\end{array}$ & $\begin{array}{c}\mathbf{1}^{\text {st }} \\
\text { season }\end{array}$ & $\begin{array}{c}\mathbf{2}^{\text {nd }} \\
\text { season }\end{array}$ \\
\hline $\mathbf{C}$ & $98.07 \mathrm{D}$ & $89.1 \mathrm{E}$ & $20.93 \mathrm{C}$ & $23.53 \mathrm{D}$ & $1.23 \mathrm{D}$ & $1.06 \mathrm{D}$ & $6.40 \mathrm{D}$ & $5.50 \mathrm{D}$ \\
$\mathbf{C} / \mathbf{S h}$ & $136.2 \mathrm{~A}$ & $150.1 \mathrm{~A}$ & $34.30 \mathrm{~A}$ & $41.78 \mathrm{~A}$ & $2.533 \mathrm{~A}$ & $2.683 \mathrm{~A}$ & $13.17 \mathrm{~A}$ & $13.93 \mathrm{~A}$ \\
$\mathbf{C} / \mathbf{F}$ & $123.3 \mathrm{~B}$ & $127.1 \mathrm{BC}$ & $31.93 \mathrm{AB}$ & $37.50 \mathrm{~B}$ & $1.963 \mathrm{~B}$ & $2.533 \mathrm{~A}$ & $10.20 \mathrm{~B}$ & $13.17 \mathrm{~A}$ \\
$\mathbf{C} / \mathbf{P}$ & $109.5 \mathrm{C}$ & $96.63 \mathrm{D}$ & $23.18 \mathrm{C}$ & $26.75 \mathrm{D}$ & $1.467 \mathrm{D}$ & $1.367 \mathrm{C}$ & $7.633 \mathrm{CD}$ & $7.100 \mathrm{C}$ \\
$\mathbf{C} / \mathbf{B}$ & $102.4 \mathrm{CD}$ & $126.0 \mathrm{C}$ & $23.67 \mathrm{C}$ & $25.90 \mathrm{D}$ & $1.700 \mathrm{C}$ & $1.567 \mathrm{BC}$ & $8.833 \mathrm{BC}$ & $8.167 \mathrm{BC}$ \\
$\mathbf{C} / \mathbf{S q}$ & $97.90 \mathrm{D}$ & $133.6 \mathrm{~B}$ & $29.30 \mathrm{~B}$ & $32.05 \mathrm{C}$ & $1.633 \mathrm{CD}$ & $1.700 \mathrm{~B}$ & $8.500 \mathrm{C}$ & $8.833 \mathrm{~B}$ \\
\hline
\end{tabular}

Means followed by the same letter are statistically not significant according Duncan's multiple rang test $(P=0.05)$.
C: Cucumber
Sh: Shintoza
F: Ferro P: Pumpkin
B: Bottle Gourd Sq: Squash

Table 7. Effect of grafting on Eshrak cucumber plant leaf relative water content (LRWC \%), membrane permeability (\%), free proline and chlorophyll reading of cucumber during (2014/2015 and 2015/2016) seasons.

\begin{tabular}{|c|c|c|c|c|c|c|c|c|}
\hline \multirow{2}{*}{$\begin{array}{l}\text { Treatments } \\
\text { Scion/stocks }\end{array}$} & \multicolumn{2}{|c|}{$\begin{array}{l}\text { LRWC } \\
(\%)\end{array}$} & \multicolumn{2}{|c|}{$\begin{array}{c}\text { Membrane permeabil- } \\
\text { ity (\%) }\end{array}$} & \multicolumn{2}{|c|}{$\begin{array}{c}\text { Free Proline } \\
(\mu \mathrm{mol} / 100 \mathrm{~g} \mathrm{FW})\end{array}$} & \multicolumn{2}{|c|}{$\begin{array}{c}\text { Chlorophyll reading } \\
\text { (SPAD) }\end{array}$} \\
\hline & $\begin{array}{c}1^{\text {st }} \\
\text { season }\end{array}$ & $\begin{array}{c}2^{\text {nd }} \\
\text { season }\end{array}$ & $\begin{array}{c}1^{\text {st }} \\
\text { season }\end{array}$ & $\begin{array}{c}2^{\text {nd }} \\
\text { season } \\
\end{array}$ & $\begin{array}{c}1^{\text {st }} \\
\text { season }\end{array}$ & $\begin{array}{c}2^{\text {nd }} \\
\text { season }\end{array}$ & $\begin{array}{c}1^{\text {st }} \\
\text { season }\end{array}$ & $\begin{array}{c}2^{\text {nd }} \\
\text { season }\end{array}$ \\
\hline C & $73.75 \mathrm{C}$ & $76.55 \mathrm{C}$ & $28.85 \mathrm{~A}$ & $31.18 \mathrm{~A}$ & $87.25 \mathrm{D}$ & $105.9 \mathrm{E}$ & $35.80 \mathrm{~B}$ & $37.10 \mathrm{BC}$ \\
\hline $\mathrm{C} / \mathrm{Sh}$ & 83.48 B & $87.59 \mathrm{~A}$ & $21.39 \mathrm{C}$ & 23.63 CD & $151.7 \mathrm{~A}$ & $226.4 \mathrm{~A}$ & $36.47 \mathrm{AB}$ & $41.73 \mathrm{~A}$ \\
\hline $\mathbf{C} / \mathbf{F}$ & $88.70 \mathrm{~A}$ & $88.38 \mathrm{~A}$ & $23.52 \mathrm{BC}$ & $22.86 \mathrm{D}$ & $138.1 \mathrm{~B}$ & $132.0 \mathrm{D}$ & $40.23 \mathrm{~A}$ & $39.97 \mathrm{AB}$ \\
\hline $\mathbf{C} / \mathbf{P}$ & $84.18 \mathrm{~B}$ & $81.56 \mathrm{~B}$ & $26.36 \mathrm{AB}$ & $26.15 \mathrm{~B}$ & $132.3 \mathrm{~B}$ & $155.7 \mathrm{~B}$ & $35.27 \mathrm{~B}$ & $37.00 \mathrm{BC}$ \\
\hline $\mathbf{C} / \mathbf{B}$ & 82.09 B & 81.48 B & $26.61 \mathrm{AB}$ & $25.03 \mathrm{BC}$ & $100.6 \mathrm{C}$ & $140.7 \mathrm{C}$ & $36.57 \mathrm{AB}$ & $35.23 \mathrm{C}$ \\
\hline $\mathrm{C} / \mathrm{Sq}$ & $85.06 \mathrm{AB}$ & $78.19 \mathrm{BC}$ & $25.17 \mathrm{AB}$ & 26.37 B & $137.9 \mathrm{~B}$ & $149.7 \mathrm{~B}$ & $36.17 \mathrm{AB}$ & $35.80 \mathrm{BC}$ \\
\hline
\end{tabular}

Means followed by the same letter are statistically not significant according Duncan's multiple rang test $(P=0.05)$

C: Cucumber Sh: Shintoza F: Ferro P: Pumpkin B: Bottle Gourd Sq: Squash

\section{B- Membrane permeability (\%)}

Data in Table (7) showed that the highest percentage of membrane permeability was recorded with ungrafted cucumber Plants (Control), Eshrak/ Pumpkin, Eshrak/Bottle Gourd and Eshrak/Squash with no significant differences among them in the first season while in the second season, the highest percentage was shown with ungrafted cucumber plants as compared to all graft combinations. The lowest percentage was observed with grafted cucumber on Shintoza in the first season and it was with grafted cucumber on Ferro in the second season. These results are in agreement with that recorded by Chen and Wang (2008) stated that the cell membrane permeability in leaves was much less in grafted plant than ungrafted ones.

\section{C- Proline content}

Differences among the different graft combinations in proline contents are shown in Table (7). Grafted cucumber on Shintozagave the highest value of proline content as compared to all graft combinations. Cucumber (ungrafted) plants had the lowest value of proline content in both seasons.In accordance with our results, proline content increased in watermelon (Yang et al 2012) and grafted pepper (Penella et al 2015) under salt stress.

\section{D- Chlorophyll reading (SPAD)}

Data in Table (7) showed that the highest value of chlorophyll was found with grafted cucumber on Ferro, Shintoza, Bottle Gourd and Squash without 

under saline conditions

significant differences among them in the first season while in the second season; it was with cucumber grafted on Shintoza and Ferro without significant differences between them as compared with to all graft combinations. The lowest value was obtained from grafted cucumber on pumpkin and ungrafted cucumber in the first season and it was when cucumber grafted on bottle gourd in the second season. These results are in agreement with those of Colla et al (2013) and Wang Qing et al (2017).

\section{E- Sodium \% in shoots}

Regards the sodium \% in shoots, Data in Table (8) showed that the lowest \% was found with grafted plants than ungrafted plants in both seasons. The highest value was recorded in cv. Eshrak ungrafted cucumber in both seasons while the lowest value in shoots was recorded in Eshrak/ Pumpkin in the first season and with Eshrak/Shintoza, Eshrak/ Ferro and Eshrak/ Bottle Gourd in the second season. These results are in agreement with that stated by Wang Qing et al (2017) and Yarsi et al (2017).

\section{F- Sodium $\%$ in roots}

Regards the sodium \% in roots, the highest value was found in grafted plants than ungrafted in both seasons. The highest \% of $\mathrm{Na}$ in root was obtained from Eshrak/ Pumpkin, Eshrak/ Squash, Eshrak/Shintoza in the first season while in the second season, it was Eshrak/ Ferro. The lowest value of $\mathrm{Na} \%$ in root was recorded in Eshrak/ bottle gourd and ungrafted Eshrak in the first season and it was with ungrafted plants (control) in the second season. Our data confirmed that grafted cucumber plants outperformed those ungrafted ones for their growth and yield characteristics under $\mathrm{NaCl}$ induced stress. This may be attributed to the accumulation of $\mathrm{Na}$ in the roots more than in the leaves in grafted plants. These results are in agreement with those of Chen and Wang (2008) on cucumber seedlings and Lei Bo et al (2014 b) on pumpkin.

\section{G- Chloride \% in shoots}

Data in Table (8) showed that the lowest \% was found in grafted plants than ungrafted plants in both seasons. The highest \% was detected in Eshrak (ungrafted) cucumber in both seasons whereas the lowest $\% \mathrm{Cl}$ in shoots was found in Eshrak/Ferro and Eshrak/ bottle gourd in the first season and it was with Eshrak/ Pumpkin in the second season. The results of Huang Yuan et al (2009 b) and Gul et al (2017) confirm these results.

\section{$\mathrm{H}$ - Chloride \% in roots}

The highest value was found in grafted Eshrak/ bottle gourd in the first season while in the second season, it was with Eshrak/Shintoza.While the lowest concentration of $\mathrm{Cl}$ in roots was found in ungrafted Eshrak in both seasons (Table 8). Such results were recorded by Romero et al (1997), Saccardo et al (2006) and Huang Yuan et al (2009 b).

Table 8. Effect of grafting on Eshrak cucumber plant sodium \% and chloride \% in shoots and roots of cucumber during (2014/2015 and 2015/2016) seasons.

\begin{tabular}{|c|c|c|c|c|c|c|c|c|}
\hline \multirow{2}{*}{$\begin{array}{l}\text { Treatments } \\
\text { Scion/stocks }\end{array}$} & \multicolumn{2}{|c|}{$\begin{array}{l}\text { Sodium in the } \\
\text { shoot } \%\end{array}$} & \multicolumn{2}{|c|}{ Sodium in the root $\%$} & \multicolumn{2}{|c|}{$\begin{array}{c}\text { Chloride in the shoot } \\
\%\end{array}$} & \multicolumn{2}{|c|}{ Chloride the root \% } \\
\hline & $\begin{array}{c}1^{\text {st }} \\
\text { Season }\end{array}$ & $\begin{array}{c}2^{\text {nd }} \\
\text { season }\end{array}$ & $\begin{array}{c}1^{\text {st }} \\
\text { Season }\end{array}$ & $\begin{array}{c}2^{\text {nd }} \\
\text { season }\end{array}$ & $\begin{array}{c}1^{\text {st }} \\
\text { Season }\end{array}$ & $\begin{array}{c}2^{\text {nd }} \\
\text { season }\end{array}$ & $\begin{array}{c}1^{\text {st }} \\
\text { Season }\end{array}$ & $\begin{array}{c}2^{\text {nd }} \\
\text { season }\end{array}$ \\
\hline C & $5.20 \mathrm{~A}$ & $5.69 \mathrm{~A}$ & $6.97 \mathrm{C}$ & $6.13 \mathrm{D}$ & $51.63 \mathrm{~A}$ & $61.84 \mathrm{~A}$ & $27.22 \mathrm{D}$ & $36.46 \mathrm{E}$ \\
\hline C / Sh & 4.17BC & $3.03 \mathrm{C}$ & $10.50 \mathrm{AB}$ & $11.26 \mathrm{C}$ & $37.42 \mathrm{~B}$ & $38.31 \mathrm{C}$ & $38.33 \mathrm{C}$ & $64.97 \mathrm{~A}$ \\
\hline $\mathrm{C} / \mathrm{F}$ & 3.77BC & $2.43 \mathrm{C}$ & 7.87BC & $19.83 \mathrm{~A}$ & $24.90 \mathrm{C}$ & $40.00 \mathrm{BC}$ & $39.40 \mathrm{C}$ & $54.69 \mathrm{C}$ \\
\hline $\mathbf{C} / \mathbf{P}$ & $3.33 \mathrm{C}$ & $4.07 \mathrm{~B}$ & $11.07 \mathrm{~A}$ & 13.96BC & $37.22 B$ & $34.85 \mathrm{D}$ & $52.58 \mathrm{~B}$ & $59.25 \mathrm{~B}$ \\
\hline C / B & 3.77BC & $2.80 \mathrm{C}$ & $6.63 \mathrm{C}$ & 16.77B & $24.11 \mathrm{C}$ & 40.69BC & $55.63 \mathrm{~A}$ & $52.44 \mathrm{C}$ \\
\hline $\mathrm{C} / \mathrm{Sq}$ & 4.57AB & $3.40 \mathrm{BC}$ & $10.97 \mathrm{~A}$ & $11.57 \mathrm{C}$ & $34.49 \mathrm{~B}$ & $42.09 \mathrm{~B}$ & $51.62 \mathrm{~B}$ & 45.98D \\
\hline
\end{tabular}

Means followed by the same letter are statistically not significant according Duncan's multiple rang test $(P=0.05)$.

C: Cucumber Sh: Shintoza F: Ferro P: Pumpkin B: Bottle Gourd Sq: Squash 


\section{4- Effect of grafting on physical and chemical fruit characteristics}

Concerning firmness in cucumber fruits. Data presented in Table (9) showed that there were significant differences among different rootstocks regard fruit firmness. The highest value was recorded in Eshrak/Shintoza, Eshrak/Ferro and Eshrak/ pumpkin without significant differences in the first season and it was with Eshrak/Shintoza in second seasons. While the lowest value of fruits firmness was recorded in Eshrak ungrafted cucumber without significant differences with Eshrak/squash in both seasons. Colla et al (2006 a) confirm these results.

Concerning potassium $\%$ in fruit, results showed no significant differences among graft combinations and Eshrak (ungrafted) plants in both seasons (Table 9).

Concerning total soluble solids in cucumber fruits. Using bottle gourd and pumpkin as root- stocks led to clear increments in the total soluble solids in fruit scion compared with Squash and Ferro rootstocks. The highest TSS \% was recorded in all used treatments except Eshrak/Squash in both seasons and Eshrak/Ferro in the second season which had the lowest concentration. Our results agree with those reported by Colla et al (2006 b), Colla et al (2007), Huang Yuan et al (2009 a) and Colla et al (2013).

Concerning sodium \% in cucumber fruits. Grafting was found to play an important role in increasing fruit quality concerning $\mathrm{Na} \%$ in fruit (Table 9). The lowest \% was found in grafted plants than ungrafted plants in both seasons. The highest value was recorded in Eshrak (ungrafted) cucumber in both seasons. While the lowest $\mathrm{Na}$ value in fruits was recorded in Eshrak/Shintoza and Eshrak/ bottle gourd in the first season and it was from Eshrak/Shintoza in the second season.Similar results were obtained by Huang Yuan et al (2009 a).

Table 9. Effect of grafting on Eshrak cucumber plantSodium (fruit, mg/g), Potassium (\%), TSS (\%) and Firmness $\left(\mathrm{Kg} / \mathrm{cm}^{2}\right)$ of Fruit cucumber during (2014/2015 and 2015/2016) seasons.

\begin{tabular}{|c|c|c|c|c|c|c|c|c|c|c|}
\hline Treatments & \multicolumn{2}{|c|}{ Firmness $\left(\mathrm{Kg} / \mathrm{cm}^{2}\right)$} & \multicolumn{3}{|c|}{ Potassium (\%) } & \multicolumn{3}{|c|}{ TSS (\%) } & \multicolumn{2}{|c|}{ Sodium (\%) } \\
\hline $\begin{array}{l}\text { Scion / } \\
\text { stocks }\end{array}$ & $\begin{array}{c}1^{\text {st }} \\
\text { season }\end{array}$ & $\begin{array}{c}2^{\text {nd }} \\
\text { season }\end{array}$ & $\begin{array}{c}1^{\text {st }} \\
\text { season }\end{array}$ & $\begin{array}{r}2 \\
\text { sea } \\
\end{array}$ & & $\begin{array}{r}1 \\
\text { sea } \\
\end{array}$ & & $\begin{array}{c}2^{\text {nd }} \\
\text { season }\end{array}$ & $\begin{array}{c}1^{\text {st }} \\
\text { season }\end{array}$ & $\begin{array}{c}2^{\text {nd }} \\
\text { season }\end{array}$ \\
\hline C & $61.4 \mathrm{C}$ & $61.3 \mathrm{D}$ & $1.32 \mathrm{~A}$ & 1.17 & A & 4.50 & A & $5.53 \mathrm{~A}$ & $0.06 \mathrm{~A}$ & $0.06 \mathrm{~A}$ \\
\hline $\mathrm{C} / \mathrm{Sh}$ & $63.7 \mathrm{~A}$ & $64.6 \mathrm{~A}$ & $1.28 \mathrm{~A}$ & 1.39 & A & 4.40 & A & $4.70 \mathrm{AB}$ & $0.03 \mathrm{C}$ & $0.02 \mathrm{D}$ \\
\hline $\mathrm{C} / \mathrm{F}$ & $63.4 \mathrm{AB}$ & $62.4 \mathrm{C}$ & $1.32 \mathrm{~A}$ & 1.33 & A & 4.60 & A & 4.10 BC & $0.05 \mathrm{AC}$ & $0.04 \mathrm{CD}$ \\
\hline $\mathbf{C} / \mathbf{P}$ & $63.2 \mathrm{~B}$ & $63.3 \mathrm{BC}$ & $1.21 \mathrm{~A}$ & 1.20 & A & 4.40 & A & $5.63 \mathrm{~A}$ & $0.04 \mathrm{BC}$ & $0.06 \mathrm{AB}$ \\
\hline C / B & $62.7 \mathrm{~B}$ & $63.4 \mathrm{~B}$ & $1.20 \mathrm{~A}$ & 1.24 & A & 4.77 & A & $5.27 \mathrm{~A}$ & $0.04 \mathrm{C}$ & $0.05 \mathrm{BC}$ \\
\hline $\mathrm{C} / \mathrm{Sq}$ & $60.7 \mathrm{C}$ & $60.8 \mathrm{D}$ & $1.39 \mathrm{~A}$ & 1.37 & A & 3.23 & B & $3.53 \mathrm{C}$ & $0.05 \mathrm{AB}$ & $0.03 \mathrm{CD}$ \\
\hline
\end{tabular}

Means followed by the same letter are statistically not significant according Duncan's multiple rang test $(P=0.05)$.
C: Cucumber
Sh: Shintoza F: Ferro
P: Pumpkin $\quad B$ :
B: Bottle Gourd Sq: Squash

\section{CONCLUSION}

The results indicated that certain rootstock genotypes were able to tolerate high salt. Plants of Eshrak/Shintoza had better total yield per feddan (similar to Eshrak/Ferro) and fruit quality compared with other graft combinations. All graft combinations accumulated more $\mathrm{Na}$ in their roots than ungrafted plants which may explain the relative tolerance of these plants to salinity stress.

\section{REFERENCES}

A.O.A.C., 1996. Official Methods of Analysis. $12^{\text {th }}$ ed. Washington, DC: AOAC.
Chen, G. and Wang R., 2008. Effects of salinity on growth and concentrations of sodium, potassium, and calcium in grafted cucumber seedlings. Acta Horticulturae, 771, 217-224.

Colla, G., Rouphael Y., Cardarelli M., Massa D., Salerno A. and Rea E., 2006a. Yield, fruit quality and mineral composition of grafted melon plants grown under saline conditions. Journal of Horticultural Science and Biotechnology 81(1), 146-152.

Colla, G., Roupahel Y., Cardarelli M. and Rea E., 2006b. Effect of salinity on yield, fruit quality, leaf gas exchange, and mineral composition of grafted watermelon plants. Hort Science, 41(3), 622-627. 

under saline conditions

Colla, G., Rouphael Y., Cardarelli M., Temperini O., Fanasca S., Pierandrei F., Salerno A. and Rea E., 2007. Salt tolerance and mineral relations for grafted and ungrafted watermelon plants grown in NFT. Acta Horticulturae, 747, 243-247.

Colla, G. Cardarelli M. and Leonardi C. 2010a. Grafting of vegetable crops: potential and prospectives. [Italian] Italus Hortus, 17 (6), 9-14.

Colla, G., Rouphael Y., Leonardi C. and Bie Z. 2010b. Role of grafting in vegetable crops grown under saline conditions. (Special Issue on Vegetable Grafting). Scientia Horticulturae, 127(2), 147-155.

Colla, G., Rouphael Y., Rea E. and Cardarelli M. 2012. Grafting cucumber plants enhance tolerance to sodium chloride and sulfate salinization. Scientia Horticulturae, 135, 177-185.

Colla, G. Rouphael, Y. Jawad R., Kumar P., Rea E. and Cardarelli M., 2013. The effectiveness of grafting to improve $\mathrm{NaCl}$ and $\mathrm{CaCl}_{2}$ tolerance in cucumber. Scientia Horticulturae, 164, 380-391.

Davis, A.R.P., Perkins-Veazie, Y., Sakata, S.L., Pez-Galarza, Maroto J.V., Lee S., Huh Y., Sun Z.A., Miguel, S.R., King; R., Cohen and Lee J. 2008. Cucurbit grafting. Critical Reviews in Plant Sciences, 27 (1), 50-74.

El-Shraiy, A.M., Mostafa M.A., Zaghlool S.A. and Shehata S.A.M., 2011. Alleviation of salt injury of cucumber plant by grafting onto salt tolerance rootstock. Australian Journal of Basic and Applied Sciences, 5 (10),14141423.

El-Wanis, M.M.A., Abdel-Baky M.H. and Salman S.R., 2012. Effect of grafting and salt stress on the growth, yield and quality of cucumber grown in NFT system. Journal of Applied Sciences Research, 8(10). 5059-5067.

Fallik, E. and Ilic Z., 2014. Grafted vegetablesthe influence of rootstock and scion on postharvest quality. Folia Horticulturae, 26 (2), 7990.

Farhadi, A. and Rezaie M., 2015. Evaluation of quantitative and qualitative traits of greenhouse cucumber (Cucumis sativus L. 'Khassib') grafted on different Cucurbita rootstocks. Acta Horticulturae, 1086, 279-283.

Gomez, K.A. and Gomez A.A., 1983. Statistical Procedures of Agric. Res. $2^{\text {nd }}$ Ed. John Wiley and Sons Pub., USA. pp. 139-153

Gul, A., Cengiz O. and Tepecik M., 2017. the effect of grafting on salinity tolerance in cu- cumber plants grown in perlite. Acta Horticulturae, 1170, 1165-1172.

Huang Y., Tang R., Cao Q. and Bie Z. 2009a. Improving the fruit yield and quality of cucumber by grafting onto the salt tolerant rootstock under $\mathrm{NaCl}$ stress. Scientia Horticulturae, 122 (1), 26-31.

Huang Yuan, Zhu Jin, Zhen Ai, Chen LiAng and BieZhiLong, 2009b. Organic and inorganic solutes accumulation in the leaves and roots of grafted and ungrafted cucumber plants in response to $\mathrm{NaCl}$ stress. Journal of Food, Agriculture \& Environment, 7(2), 703-708.

Jackson, M.L., 1967. Soil Chemical Analysis. Prentice-Hall, Inc., Englewood Cliffs, N.J., Library of Congress, USA, pp,. 498..

King, S.R., Davis, A.R., Zhang X.P. and Crosby K., 2010. Genetics, breeding and selection of rootstocks for Solanaceae and Cucurbitaceae. (Special Issue on Vegetable Grafting. Scientia Horticulturae, 127 (2), 106-111.

Lei Bo, Huang Yuan, Sun JingYu, XieJunJun, NiuMengLiang; Liu ZhiXiong; Fan MoLin and BieZhiLong 2014a. Scanning ionselective electrode technique and $\mathrm{x}$-ray microanalysis provide direct evidence of contrasting $\mathrm{Na}+$ transport ability from root to shoot in saltsensitive cucumber and salt-tolerant pumpkin under $\mathrm{NaCl}$ stress. Physiologia Plantarum, 152 (4), 738-748.

Lei, B., Huang Y., Xie J.J., Liu Z.X., Zhen A., Fan M.L. Bie and Z.L., 2014b. Increased cucumber salt tolerance by grafting on pumpkin rootstock and after application of calcium. Biologia Plantarum, 58 (1), 179-184.

Marsic, N.K. and Jakse M., 2010. Growth and yield of grafted cucumber (Cucumis Sativus L.) on different soilless substrates. Journal of Food, Agriculture \& Environment 8(2), 654658.

Mohamed, F.H., El-Hamed K.A., Elwan M.W.M. and Hussien M.N.E., 2014. Evaluation of different grafting methods and rootstocks in watermelon grown in Egypt. Scientia Horticulturae, 168, 145-150.

Penella, C., Nebauer S.G., Quinones A., San Bautista A., Lopez-Galarza S. and Calatayud A., 2015. Some rootstocks improve pepper tolerance to mild salinity through ionic regulation. Plant Science, 230, 12-22.

Petropoulos, S.A., Olympios C., Ntatsi G., Akoumianakis C. and Passam H., 2012. Effects of grafting and salinity on agronomic characteristics and ion uptake by cucumber 
plants grown in a closed hydroponic system. Acta Horticulturae, 952, 637-643.

Ramsay, J.A., Brown R.H.J. and Croghan P.C., 1955. Electrometric titration of chloride in small volumes. Journal of Experimental Biology, 32, 822-829.

Romero, L., Belakbir A., Ragala L. and Ruiz J.M., 1997. Response of plant yield and leaf pigments to saline conditions: effectiveness of different rootstocks in melon plants (Cucumis melo L.). Soil Science and Plant Nutrition 43 (4), 855- 862.

Rouphael, Y., Venema J.H., Edelstein M., Savvas D., Colla G., Ntatsi G., Ben-Hur M., Pradeep Kumar and Schwarz D., 2017. Grafting as a tool for tolerance of abiotic stress. Vegetable grafting: Principles and Practices, 171215.

Saccardo, F., Colla G., Crino P., Paratore A., Cassaniti C. and Temperini O., 2006. Genetic and physiological aspects of grafting in vegetable crop production. [Italian] Italus Hortus, 13(1), 71-84.

Sadasivam, S. and Manickam A., 1992. Biochemical Methods for Agricultural Sciences. Wiley Eastern Limited, pp, 246.

Shi, Q., Bao Z., Zhu Z., Ying Q. and Qian Q., 2006. Effect of different treatments of salicylic acid on heat tolerance, chlorophyll fluorescence, and antioxidant enzyme activity in seedlings of cucumis sativa L. Plant Growth Regulation, 48, 127-135.

Singh, P.K. and Rao K.M., 2014. Role of grafting in cucurbitaceous crops- a review. Agricultural Reviews, 35 (1), 24-33.

Wang LiPing, Sun Jin, GuoShiRong, Tian Jing and Yang YanJuan, (2012). Effects of graft with pumpkin rootstock on nitrogen metabolism and protein expression in the cucumber seedlings under iso-osmotic $\mathrm{Ca}\left(\mathrm{NO}_{3}\right)_{2}$ or $\mathrm{NaCl}$ stress. Chinese] Plant Nutrition and Fertilizer Science, 18(3), 689-698.
Wang Q., Men L., Gao L.H., TianYong Q. 2017. Effect of grafting and gypsum application on cucumber (Cucumis sativus L.) growth under saline water irrigation. Agricultural Water Management, 188, 79-90.

Yamasaki, S. and Dillenburg L.R. 1999. Measurements of leaf relative water content in Araucaria angustifolia. Revista Brasilleirade fisiologia vegetal, 11(2), 69-75.

Yang, Y., Wang L., Tian J., Li J., Sun J., L. He, Guo S. and Tezuka T., 2012. Proteomic study participating the enhancement of growth and salt tolerance of bottle gourd rootstock- grafted watermelon seedlings. Plant Physiology and Biochemistry, 58, 54-65.

Yang YanJuan, Yu L., Wang L. and Guo S.R. 2015. Bottle gourd rootstock-grafting promotes photosynthesis by regulating the stomata and non-stomata performances in leaves of watermelon seedlings under $\mathrm{NaCl}$ stress. Journal of Plant Physiology, 186/187, 50-58.

Yars, G., Svac A., Dasgan H.Y., Altuntas O., Bnzet R. and Akhoundnejad Y., 2017. Effects of salinity stress on chlorophyll and carotenoid contents and stomata size of grafted and ungrafted Galia C8 melon cultivar. Pakistan Journal of Botany, 49(2), 421-426.

Yarsi, G., Altuntas O., Svac A. and Dasgan H.Y., 2017. Effects of salinity stress on plant growth and mineral composition of grafted and ungrafted Galia C8 melon cultivar. Pakistan Journal of Botany, 49 (3), 819-822.

Zhao Y. and Wu F. 2014. Effects of saline stress on growth and rhizoplane soil enzyme activities of cucumber seedling grafted on different rootstocks. China Vegetables, (5), 33-38.

Zhou J., Hu H., Li X., Zhao R., Li G. and Yang P. 2010. Effects of rootstock on fruit yield and quality of hydroponically cultivated grafted cucumber under $\mathrm{NaCl}$ stress. Acta Horticulturae, 871, 63-70. 
المؤتمر الرابع عثر لبحوث التنمية الزراعية،

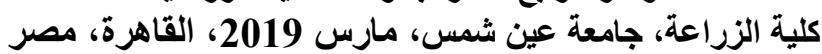

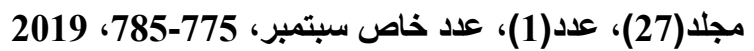

Website: http://strategy-plan.asu.edu.eg/AUJASCI/

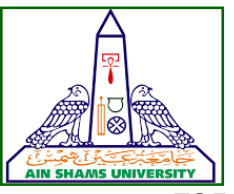

تحسين المحصول الثمري والجوده فى الخيار بالتطعيم على أصول مختلفة

\section{تحت الظروف الملحية}

[71]

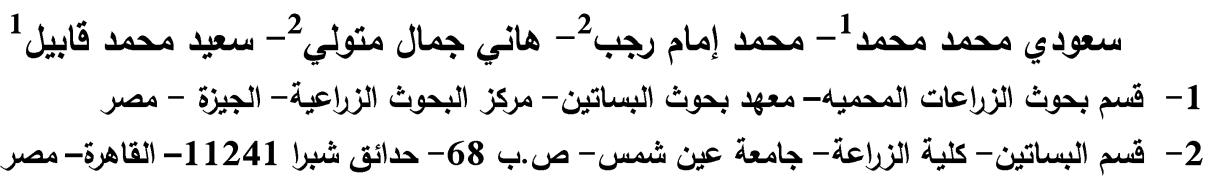

*Corresponding author: Mohamed_emam@agr.asu.edu.eg

Received 16 September, 2018, Accepted 25 September, 2018

بالنسبة للوزن الطـازج للثمار ، عدد الثمار ، المحصـول

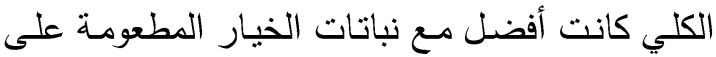

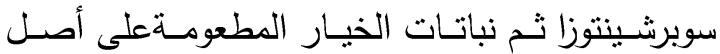

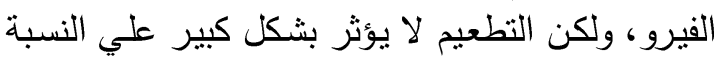

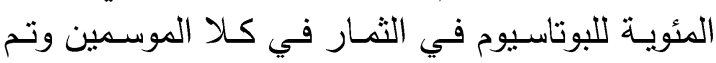

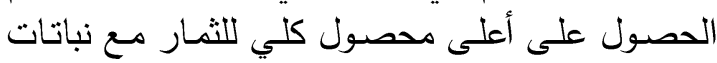
الخيار المطعومـة على سوبرشينتوزا ثم نباتات الخيار الفيار

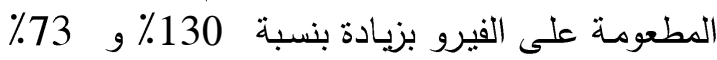

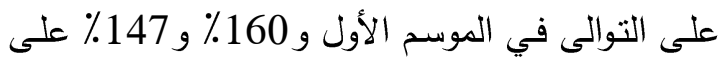

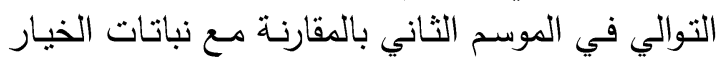

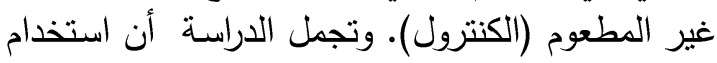

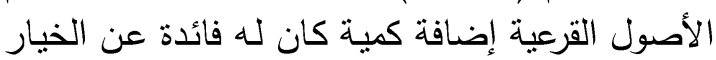
غير المطعوم في الموسمين.

الكلمات الدالة: خيار، الإجهاد الملحي، التطعيم

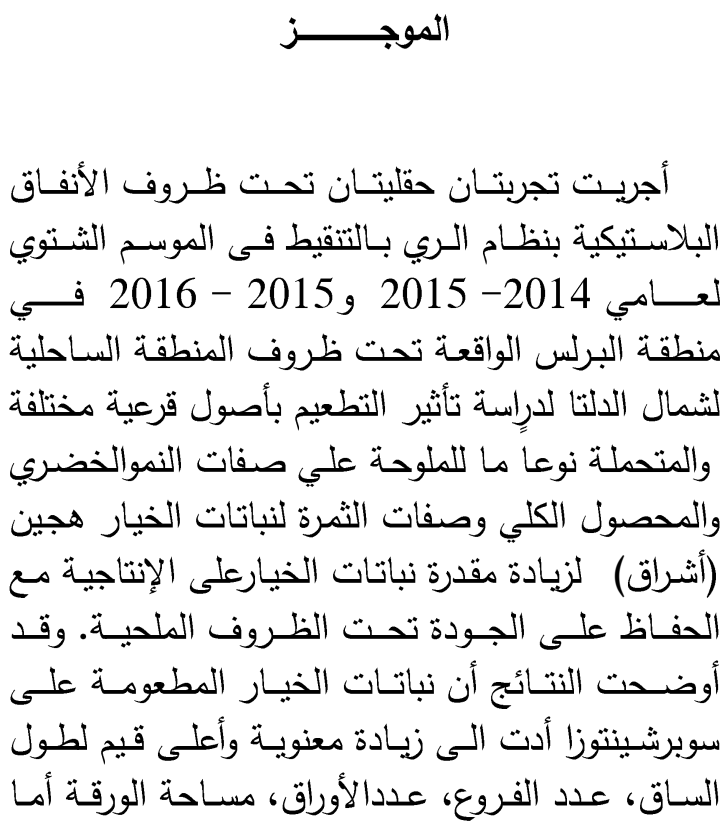

تحكيم: ا.دد أسامة أحمد البحيري

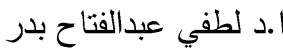

